COGNitive STUdies | Études COGNitives, 11

SOW Publishing House, Warsaw 2011

\title{
KATARZYNA POPEK-BERNAT
}

Institute of Iberian and Ibero-American Studies, Faculty of Modern Languages, University of Warsaw, Warsaw

(k.popek@student.uw.edu.pl)

\section{THE CONCEPTUAL IMAGES OF EROTIC RELATIONS IN SPANISH. ANALYSIS OF SOME LINGUISTIC ASPECTS OF THE TURKISH PASSION BY ANTONIO GALA.}

\begin{abstract}
In this paper we try to systematize the contemporary Spanish expressions related to the erotic relations. The corpus is based on the novel by Antonio Gala The Turkish Passion (orig. La pasión turca) which, thanks to its plot with higly erotic content, constitutes an important source of linguistic material for our investigation. The analysis we propose reflects the methodology developed by George Lakoff and Mark Johnson in their studies concerning the cognitive theory of metaphor. According to them, every concept consists of a source and a target domain and while expressing one idea we refer to another (Lakoff \& Johnson 1980: 56). Our analysis focuses on the reconstruction of the conceptual domains by means of which the Spanish writer describes the erotic relations. Although the book does not include all the erotic vocabulary and expressions which exist in contemporary Spanish, it enables us to observe some regularities in the use of metaphors in Spanish and reveal some sociocultural phenomena encoded in the linguistic material.

Keywords: eroticism, Antonio Gala, cognitive metaphor, Spanish, linguistic conceptualization, erotic relations, desire, lust, sexual act, physical love.
\end{abstract}

\section{Introduction}

The following article is connected with an interdisciplinary project developed by a group of researchers from the Institute of Iberian and Ibero-American Studies at the University of Warsaw, concerning the categorization of erotic relations in Spanish and Polish literature created in the last 40 years. The aim of this paper is to try to systematize the contemporary Spanish expressions related to the erotic relations. The linguistic corpus is based on the novel by Antonio Gala The Turkish Passion (orig. La pasión turca).

The book has not been chosen at random as it is one of the most popular Spanish bestsellers of the last two decades and, thanks to its plot with highly erotic 
content, it is an important source of linguistic material which constitutes the object of our investigation. Furthermore, it is quite significant that the novel belongs to the literature created after the political transformation in Spain initiated in 1975. The birth of democracy in Spanish society was linked to some ideological changes. According to the hypothesis of Sapir and Whorf that the language affects the way of thinking of its speakers and that, in this sense, the act of thinking is always verbal (Shaff 1982: 5-29), the language is first to reflect the sociocultural evolution. Such a "daring" literature like the novel by Gala did not exist in the Iberian Peninsula before Franco's death, because the restrictions imposed by the totalitarian system were felt in all spheres of life and, logically, in the language itself as well. Eroticism was undoubtedly one of the greatest taboos of that period. Nevertheless since 1975, the Spanish society has become more open-minded, more liberal and, as a result, more "creative" in linguistic terms. In this sense, the transformation has contributed to the enrichment of the language.

Our analysis of the linguistic aspects of the novel of Antonio Gala focuses on the reconstruction of the conceptual images by means of which the Spanish writer describes the erotic relations. Obviously, the book does not include all the erotic vocabulary and expressions which exist in the contemporary Spanish. However, it enables us to observe some regularities in the use of metaphors in Spanish and to present some sociocultural phenomena encoded in the linguistic material.

\section{Theoretical background and methodological models}

The systematization of the Spanish erotic vocabulary we propose in this paper is based on the assumptions of the cognitive theory of metaphor developed by George Lakoff and Mark Johnson. In their framework the metaphor they consider the metaphor is central to the communication act because it shapes the human perception of the world. In other words, they claim that every concept consists of a source and a target domain and while expressing one idea we refer to another (Lakoff \& Johnson 1980: 56). It turns out that we subconsciously conceive the abstract concepts in terms of our concrete experience, i.e. love is a journey, love is war, love is madness (Lakoff, Johnson 1980: 108). According to these American researchers, the cognitive perspective applied to linguistic analysis enables us to observe the systematic character of metaphorical concepts implicit in language structures (Lakoff, Johnson 1980: 7-9).

While describing the ways of conceptualizing the erotic relations in Spanish, we should not overlook the contributions of Zoltan Kövecses and his works on emotion vocabulary, especially the book Metaphor and emotion. In his opinion, the expressions people use to talk about emotions are mainly metaphorical. Moreover the metaphors rooted in language form the cultural models which reflect the perception of emotion tied to the culture we live in (Kövecses 2000: 114-138).

Our analysis of the linguistic material from Antonio Gala's novel follows, basically, the methodology offered in the cases studies of ANGER and OVER by George Lakoff in his work Women, Fire and Dangerous Things (1986: 380-461) and in the case study of DESIRE in Spanish by Carlos Muñoz Gutiérrez (n.d.: 21-23). Nevertheless, taking into account the subject of our investigation that is connected to 
the eroticism, we adopt as well some research methods from Eliecer Crespo Fernández who, in one of his publications, presents a detailed analysis of the conceptual metaphors related to the sex-related euphemism and dysphemism (Crespo Fernández 2008: 95-110). The third model we base on while systematizing the corpus from The Turkish Passion in terms of the conceptual images of erotic relations embodied in Spanish is the study of Antonio García Olivares into some love metaphors which appear repeatedly in tango lyrics (García-Olivares 2007: 139-179).

\section{Summary of Antonio Gala's novel}

Before delving into analysis of some linguistic aspects of Antonio Gala's novel we consider necessary to provide a short summary of the book. The Turkish Passion is a history of Desideria Oliván (Desi) who, after going through a disappointing marriage, falls in love with Yamam, a Turk met by chance during her holidays in Istanbul. Attracted to Yamam, she decides to leave Spain, abandon her husband and start a new live in Turkey. The love affair turns into a turbulent relationship, filled with eroticism, that gives birth to a series of dramatic situations.

In our opinion it is particularly relevant when analyzing the erotic expressions used in the book that the novel consists of four books which are personal memories of Desi. In other words, the story is told by a female narrator, what is quite significant, not to say surprising, in reference to the male author, especially in the context of describing the erotic relations.

\section{Categories which refer to the erotic relations}

In order to be able to analyze the conceptual images of erotic relations and to avoid ambiguity we have to define first the categories which refer to this concept. In our view we should point out three of them: DESIRE or LUST [equivalents of DESEO in Spanish] - as something which precedes and evokes the erotic relation, SEXUAL ACT and PHYSICAL LOVE - as evidence of a fulfilled desire. Consequently, for the purposes of this research paper, our linguistic corpus is limited only to those expressions from the book which are directly tied to the categories mentioned above.

There are already some published studies that try to systematize the DESIRE / LUST metaphors encoded in Spanish. To be more precise, according to Carlos Muñoz Gurtiérrez, whose work we mentioned previously (Section 2), it turns out that DESIRE / LUST is conceived in Spanish in terms of: WAR [Sp. guerra], PHYSICAL FORCE [Sp. fuerza física], HUNGER [Sp. hambre], WARMTH [Sp. calor], ILLNESS [Sp. enfermedad] and GAME [Sp. juego]. At the same time, the Spanish investigator observes that A PERSON WITH DESIRE IS AN ANIMAL and A MACHINE IN OPERATION [Sp. una persona con deseo es un animal y una máquina en funcionamiento]. As we regard the DESIRE / LUST to be a basic category that designates the erotic relation (a desire can be satisfied or not - in the first case it is nothing but a sexual act or physical love), we assume that we may apply the source domains proposed by Carlos Muñoz Gutiérrez to systematize the expressions related to the concept of erotic relation in general. 


\section{Realization of the metaphors proposed by Muñoz Gutiérrez in The Turkish Passion}

Following the classification of conceptual metaphors provided by Carlos Muños Gutiérrez, we have selected and analyzed some expressions used by Antonio Gala in his novel which refer to all of the distinguished categories that designate the erotic relation. As a result we have observed that the prevailing source domains that appear in the book in this context are ILLNESS (25 realizations) and WAR (21 realizations). The examples of conceptualization of the erotic relation as an ANIMAL (more precisely, the conceptualization of a person involved in erotic relation as an animal), WARMTH or HUNGER in The Turkish Passion are less frequent but still quite numerous (aprox. 10 realizations of each of them), while the conceptual metaphors of erotic relation as a GAME, PHYSICAL FORCE or MACHINE are hardly noticeable in the text. These tendencies are well reflected in a graph presented below.

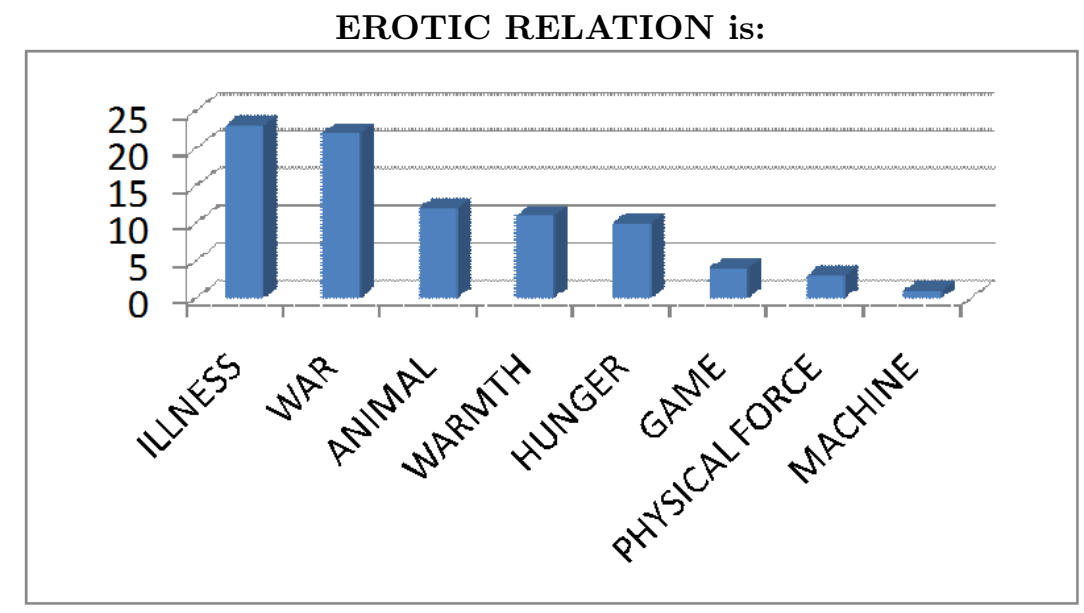

\section{Graph 1}

\subsection{Erotic relations is illness}

As far as we observed, one of the most developed source domain in Gala's book while talking about the erotic relations is ILLNESS. The most representative examples of this conceptual metaphor from the novel are shown in the table below. The analysis of the linguistic realizations of EROTIC RELATION IS ILLNESS metaphor enables us to observe some metonymic extensions of the principal source domain. Depending on the interpretation of a specific expression, in some cases it is more than noticeable that the erotic relation is not only conceptualized in terms of ILLNESS but, at the same time, in terms of MADNESS, ALTERATION IN BRAIN FUNTION and EFFORT (star marked examples). 


\begin{tabular}{|l|l|}
\hline \multicolumn{1}{|c|}{$\begin{array}{c}\text { Antonio Gala The Turkish } \\
\text { Passion }\end{array}$} & \multicolumn{1}{c|}{ Literal English translation } \\
\hline Flaquear las piernas & To falter the legs \\
\hline Yo apretaba su sexo turgente & I was pressing his plump sex \\
\hline Escalofríos / Estremecimiento & Chills / Shivering \\
\hline Con la cabeza atrás yo jadeaba & With the head back I was gasping \\
\hline Se me nubló de nuevo el mundo & The world clouded over to me again \\
\hline $\begin{array}{l}\text { Dolor espiritual y dolor del cuerpo } \\
\text { Cuerpo dolorido }\end{array}$ & $\begin{array}{l}\text { Spiritual pain and body pain / Aching } \\
\text { body }\end{array}$ \\
\hline $\begin{array}{l}\text { Estar desmadejada / enferma / descom- } \\
\text { puesta }\end{array}$ & To be weak/sick/drained \\
\hline Sudar la frente & $\begin{array}{l}\text { [To make] the forehead sweat } \rightarrow \text { *EF- } \\
\text { FORT }\end{array}$ \\
\hline Temblor & Tremor \\
\hline Ser dañado & To be damaged \\
\hline Cuerpo dolorido & Aching body \\
\hline Escuchar su propia respiración agitada & $\begin{array}{l}\text { To listen to one's own agitated breath- } \\
\text { ing } \\
\rightarrow * \text { EFFORT }\end{array}$ \\
\hline La pasión que [...] se desangra & The passion that is bleeding \\
\hline Desvanecerse & To faint \\
\hline Caminar como una sonámbula & To walk like a sleepwalker \\
\hline Perder la razón / Perder la cabeza & To lose one's head $\rightarrow *$ MADNESS \\
\hline Furor desconocido & Unkonwn fury $\rightarrow$ *MADNESS \\
\hline Estar en trance de elegir & $\begin{array}{l}\text { To be in a trance of choosing } \rightarrow \text { *AL- } \\
\text { TERATION IN BRAIN FUNC- } \\
\text { TION }\end{array}$ \\
\hline
\end{tabular}

Table 1 


\subsection{Erotic relations is war}

Other metaphor mentioned before, which is frequent in the studied text, is EROTIC RELATION IS WAR. The table below offers some interesting examples.

\begin{tabular}{|l|l|}
\hline \multicolumn{1}{|c|}{$\begin{array}{c}\text { Antonio Gala The Turkish } \\
\text { Passion }\end{array}$} & \multicolumn{1}{c|}{ Literal English translation } \\
\hline $\begin{array}{l}\text { El poder de invadir a alguien / de ano- } \\
\text { nadar a alguien }\end{array}$ & $\begin{array}{l}\text { The power to invade someone / the } \\
\text { power to annihilate someone }\end{array}$ \\
\hline $\begin{array}{l}\text { Conquista / Reconquistar a sangre y y } \\
\text { fuego }\end{array}$ & $\begin{array}{l}\text { A conquest / To Reconquer through } \\
\text { blood and fire }\end{array}$ \\
\hline Aniquilamiento & Annihilation \\
\hline Asaltar / Asalto & To assault / The assault \\
\hline Derrota / Fracaso & Defeat / Failure \\
\hline Una batalla y paz instintivas & An instinctive battle and peace \\
\hline El temor de ser agredido por el amante & The fear of being attacked by the lover \\
\hline $\begin{array}{l}\text { Nos asaltamos igual que si del asalto de- } \\
\text { pendiera nuestra vida y la tuviésemos } \\
\text { que defender rabiosamnte }\end{array}$ & $\begin{array}{l}\text { We assaulted each other as if our life de- } \\
\text { pended on it and we had to defend it } \\
\text { furiously }\end{array}$ \\
\hline Torturar & To torture \\
\hline La pasión que sueña y que combate & $\begin{array}{l}\text { The passion which is dreaming and } \\
\text { fighting }\end{array}$ \\
\hline $\begin{array}{l}\text { Ahora sí que mi corazón no sólo mi sexo } \\
\text { pudo cantar victoria }\end{array}$ & $\begin{array}{l}\text { Now my heart not only my sex could } \\
\text { claim victory }\end{array}$ \\
\hline Trofeo & Trophy \\
\hline Enzarzarse & To engage $\rightarrow$ FIGHT / CONFLICT \\
\hline
\end{tabular}

Table 2

The exploration of a WAR source domain encoded in erotic relation expressions in Antonio Gala's novel reveals one metonymic extension (star marked example). The Spanish verb "enzarsarse" means, in one sense, "to get involved in a dispute" (Diccionario CLAVE 2003: $794^{1}$ ). Therefore, in this context, the WAR source domain entails the FIGHT or CONFLICT domain.

\footnotetext{
1 The translation is ours.
} 


\subsection{A person involved in erotic relation is an animal}

While analyzing the textual realizations of the next metaphor related to the erotic relations and proposed by Carlos Muñoz Gutiérrez (A PERSON INVOLVED IN EROTIC RELATION IS AN ANIMAL), we remarked that the Spanish author, when describing the sexual acts, tends to refer, by the expressions he employs in the book, to some concrete species of the animals, i.e. dog and wolf.

\begin{tabular}{|l|l|}
\hline \multicolumn{1}{|c|}{$\begin{array}{c}\text { Antonio Gala The Turkish } \\
\text { Passion }\end{array}$} & \multicolumn{1}{c|}{ Literal English translation } \\
\hline Forma arrebatada y animal & Violent and animal way \\
\hline Actuar bajo un impuslo ciego & To act on a blind impulse \\
\hline Ferocidad & Ferocity \\
\hline $\begin{array}{l}\text { Olfateaba sus caderas estrechas y cada } \\
\text { rincón de su cuerpo }\end{array}$ & $\begin{array}{l}\text { I was sniffing his narrow hips and every } \\
\text { part of his body }\end{array}$ \\
\hline Acto sexual: un desorden de aullidos & Sexual act: a disorder of howls \\
\hline Morder la nuca / Morderle los labios & To bit the neck / To bit sb's lips \\
\hline Lamer / Lamía mis aureolas & To lick / He was licking my areolas \\
\hline
\end{tabular}

Table 3

\subsection{Erotic relation is warmth}

Other source domain of erotic relation in Spanish which has its realizations in The Turkish Passion is WARMTH, with some methonymic extensions to the FIRE domain (star marked examples).

\begin{tabular}{|l|l|}
\hline \multicolumn{1}{|c|}{$\begin{array}{c}\text { Antonio Gala The Turkish } \\
\text { Passion }\end{array}$} & \multicolumn{1}{c|}{ Literal English translation } \\
\hline $\begin{array}{l}\text { Ardor sin límites / Ardiente arrebato / } \\
\text { Enardecimiento / Amar con enardeci- } \\
\text { miento }\end{array}$ & $\begin{array}{l}\text { Unlimited ardor / Burning outburst } \\
\text { Ardor / Love with ardor }\end{array}$ \\
\hline Calor & Heat \\
\hline Derretirse & To melt \\
\hline Aparatoso incendio de mi cuerpo & A spectacular fire in my body $\rightarrow *$ FIRE \\
\hline $\begin{array}{l}\text { La incertidumbre que quema el corazón } \\
\text { / Quemarse como una vela encendida } \\
\text { por los dos cabos }\end{array}$ & $\begin{array}{l}\text { The uncertainty that burns the heart } / \\
\text { To burn like a candle lit on both ends } \rightarrow \\
\text { *FIRE }\end{array}$ \\
\hline
\end{tabular}

Table 4 


\subsection{Erotic relation is hunger}

If we focus on some quotes from the analyzed book which embody the cognitive metaphor of erotic relation as hunger, it turns out again that the systematization of DESIRE/LUST source domains in Spanish elaborated by Muñoz Gutiérrez and applied to the concept of erotic relations in general is well reflected in the novel. In the table below we can observe that the HUNGER source domain often entails the EATING source domain (star marked examples). Furthermore, for the first time we come across the phenomenon of the overlapping metaphors. The expressions morder la nuca o morderle los labios have already appeared in the context of the conceptualization of a person involved in erotic relation as an animal (subsection 5.3.)

\begin{tabular}{|l|l|}
\hline \multicolumn{1}{|c|}{$\begin{array}{c}\text { Antonio Gala The Turkish } \\
\text { Passion }\end{array}$} & \multicolumn{1}{|c|}{ Literal English translation } \\
\hline $\begin{array}{l}\text { Transmitirse una avidez sólida y confir- } \\
\text { mada }\end{array}$ & $\begin{array}{l}\text { To transmit a strong and confirmed } \\
\text { avidity }\end{array}$ \\
\hline La pasión consumida & Consumed passion \\
\hline Amor voraz & Voracious love \\
\hline Nuestro agua y nuestro pan & $\begin{array}{l}\text { Our water and our daily bread } \\
\text { *EATING }\end{array}$ \\
\hline Recipiente de la carnalidad insaciable & $\begin{array}{l}\text { Container of insatiable carnality } \rightarrow \\
\text { *EATING }\end{array}$ \\
\hline Morder la nuca / Morderle los labios & $\begin{array}{l}\text { To bit the neck / To bit sb's lips } \rightarrow \\
\text { *EATING }\end{array}$ \\
\hline Tú eres para mí la mejor delicia turca. & $\begin{array}{l}\text { You are the best Turkish delight for me. } \\
\rightarrow \text { *EATING }\end{array}$ \\
\hline Mordisqueaba mis pezones & $\begin{array}{l}\text { He was nibbling my nipples. } \\
\text { *EATING }\end{array}$ \\
\hline
\end{tabular}

Table 5 
5.6. Erotic relation is a game, physical force and a machine (in operation)

As it is shown in the graph number 1 , not all the metaphors distinguished by Muñoz Gutiérrez are so numerous in The Turkish Passion in reference to the concept of erotic relations. We managed to find only one textual realization of the MACHINE (IN OPERATION) source domain and only a few examples of the GAME and PHYSICAL FORCE source domains. Below we present only these quotes which we consider the most representatives for each metaphor.

\begin{tabular}{|l|l|}
\hline \multicolumn{1}{|c|}{$\begin{array}{c}\text { Antonio Gala The Turkish } \\
\text { Passion }\end{array}$} & \multicolumn{1}{c|}{ Literal English translation } \\
\hline \multicolumn{2}{|c|}{ EROTIC RELATION IS GAME } \\
\hline Juego de los instintos & Game of instincts \\
\hline Él jugueteaba a poseerme & He was fiddling to possess me \\
\hline \multicolumn{2}{|c|}{ EROTIC RELATION is A MACHINE (IN OPERATION) } \\
\hline Máquina de placer & The machine of pleasure \\
\hline \multicolumn{2}{|c|}{ EROTIC RELATION is PHYSICAL FORCE } \\
\hline Esfuerzo violento & Violent effort $\rightarrow$ *VIOLENCE \\
\hline Me flagelaba con su miembro & $\begin{array}{l}\text { He was whipping me with his member } \\
\rightarrow * \text { VIOLENCE }\end{array}$ \\
\hline Él restregaba su boca contra mis pechos & He rubbed his mouth against my breasts \\
\hline Torturar & To torture \\
\hline $\begin{array}{l}\text { Nos asaltamos igual si del asalto depen- } \\
\text { diera nuestra vida y la tuviéramos que } \\
\text { defender rabiosamente }\end{array}$ & $\begin{array}{l}\text { We assaulted each other as if our life de- } \\
\text { pended on it and we had to defend it } \\
\text { furiously } \rightarrow * \text { VIOLENCE }\end{array}$ \\
\hline
\end{tabular}

\section{Table 6}

It is necessary to emphasize that the PHYSICAL FORCE source domain not only has some metonymic extensions (the star marked examples related to the erotic relations may be understood in terms of the VIOLENCE source domain) but it also overlaps with the EROTIC RELATION IS WAR metaphor (see the last two examples).

\section{Other conceptual metaphors of erotic relations in The Turkish} Passion

Apart from the source domains proposed by Muñoz Gutiérrez, our analysis of the language of Antonio Gala's novel enabled us to observe that the erotic relations are conceptualized in Spanish as well in terms of INNER TRANSFORMATION, DEATH, SUBMISSION / OBEDIENCE, DOMINATION, SUFFERING / 
(PAIN), SUBMERGENCE, TRANSGRESSION / (LIBERATION OF A PRISONER), UNITY, GIFT, MAGIC, APPROACHING THE DIVINE, FOG, FORCE OF NATURE, WAKING UP, MIRACLE and COEXISTENCE OF OPPOSITES.

\subsection{Erotic relations is inner transformation}

Among the metaphors mentioned above one of the most frequent in The Turkish Passion is EROTIC RELATION as INNER TRANSFORMATION. It is interesting to observe that the INNER TRANFORMATION source domain extends to the EVICTION source domain (the last example in the chart below).

\begin{tabular}{|l|l|}
\hline \multicolumn{1}{|c|}{$\begin{array}{c}\text { Antonio Gala The Turkish } \\
\text { Passion }\end{array}$} & \multicolumn{1}{c|}{ Literal English translation } \\
\hline Transformarse & To transform oneself \\
\hline Modelar otra dentro de mi & To model another person inside of me \\
\hline El cuerpo deja de ser suyo & The body ceases to be yours \\
\hline Dejar de existir & To stop existing \\
\hline Desprenderse de sí & To divest oneself (of oneself) \\
\hline $\begin{array}{l}\text { Dejar de habitar en nuestro cuerpo e ins- } \\
\text { talarnos en el cuerpo del otro }\end{array}$ & $\begin{array}{l}\text { To stop living in one's body and settle } \\
\text { oneself in the body of another person } \rightarrow \\
\text { *EVICTION }\end{array}$ \\
\hline
\end{tabular}

Table 7

\subsection{Erotic relations is death}

Similarly to the INNER TRANSFORMATION source domain, in the novel there are quite a lot of examples of the conceptualizations of erotic relation in terms of DEATH. Moreover, as it is shown in the following table, this metaphor overlaps with two others mentioned previously, i.e. EROTIC RELATION IS INNER TRANSFORMATION [Dejar de existir] and EROTIC RELATION IS ILLNESS [Estar sin respiración]. At the same time, the DEATH source domain in at least one case entails the SUICIDE source domain (star marked example).

\begin{tabular}{|l|l|}
\hline $\begin{array}{c}\text { Antonio Gala The Turkish } \\
\text { Passion }\end{array}$ & \multicolumn{1}{c|}{ Literal English translation } \\
\hline Dejar de existir & To stop existing \\
\hline Morir de gusto & To die of pleasure \\
\hline Estar muriendo de alegría & To be dying of happiness \\
\hline Estar sin respiración & To be out of breath \\
\hline $\begin{array}{l}\text { Acatar el instinto de muerte y } \\
\text { del asesinato }\end{array}$ & To comply with the instinct of death and murder \\
\hline Saltar al vacío & To throw oneself into the void $\rightarrow$ *SUICIDE \\
\hline
\end{tabular}

Table 8 
6.3. Erotic relation is submission, suffering, submergence, transgression, domination

If we take into account the frequency of appearance of the conceptual images of erotic relations we mentioned in the section 6 , we may create a separate group of the metaphors that have approximately $5-7$ realizations in the analyzed book (each of them). As it is shown in table number 9, this group is formed by five metaphors (EROTIC RELATION IS SUBMISSION and OBEDIENCE [of Woman to Man], EROTIC RELATION IS SUFFERING / (PAIN), EROTIC RELATION IS SUBMERGENCE, EROTIC RELATION IS TRANSGRESSION / LIBERATION OF PRISONER, EROTIC RELATION IS DOMINATION [over Woman]). The DOMINATION source domain and the SUFFERING source domain overlap with the SUBMISSION source domain (cross marked examples). Moreover, the SUFFERING / (PAIN) source domain coincides as well with the ILLNESS source domain ( $c f$. table 1 and triangle marked example in table 9). As far as we have observed, only the SUBMERGENCE source domain has its metonymic extensions, as some expressions also entail the DISSOLUTION source domain (star marked example).

The following table includes only some selected textual realizations of each metaphor, not all of them.

\begin{tabular}{|c|c|}
\hline $\begin{array}{l}\text { Antonio Gala The Turkish } \\
\text { Passion }\end{array}$ & Literal English translation \\
\hline \multicolumn{2}{|c|}{$\begin{array}{c}\text { EROTIC RELATION is SUBMISSION \& OBEDIENCE (of Woman } \\
\text { to Man) }\end{array}$} \\
\hline $\begin{array}{l}\text { Desaparecía mi voluntad en la suya sin } \\
\text { defender } \\
\text { su propia independencia }\end{array}$ & $\begin{array}{l}\text { My will was disappearing in his without } \\
\text { defending its own independence }\end{array}$ \\
\hline Estaba suspendida de sus labios & I was \\
\hline $\begin{array}{l}\text { bedecí lo que mi } \\
\text { ordenaba }\end{array}$ & $\begin{array}{l}{[\ldots] \text { when I obeyed what my } \mathrm{n}} \\
\text { ordered me }[\ldots]\end{array}$ \\
\hline Quiero ser tuya. Ven ya. & I want to be yours. Come now. \\
\hline $\begin{array}{l}\text { Mi corazón se encuentra literalmente } \\
\text { embargado por un dueño. }\end{array}$ & $\begin{array}{l}\text { My heart is literally seized by the master } \\
+ \text { DOMINATION }\end{array}$ \\
\hline Ramiro la hizo suya. & $\begin{array}{l}\text { Ramiro made her his + DOMINA- } \\
\text { TION }\end{array}$ \\
\hline \multicolumn{2}{|c|}{ EROTIC RELATION is DOMINATION (over Woman) } \\
\hline Ramiro la hizo suya. & $\begin{array}{l}\text { Ramiro made her his + SUBMIS- } \\
\text { SION }\end{array}$ \\
\hline $\begin{array}{l}\text { Mi corazón se encuentra literalmente } \\
\text { embargado por un dueño }\end{array}$ & $\begin{array}{l}\text { My heart is literally seized by the master } \\
+ \text { SUBMISSION }\end{array}$ \\
\hline Un dominador y un dominado & One dominating and one dominated \\
\hline
\end{tabular}




\begin{tabular}{|c|c|}
\hline Un esclavo y un amo & A slave and a master \\
\hline Dominar por la fuerza & To dominate by force \\
\hline Poseer (hombre a la mujer) & To possess (man to woman) \\
\hline \multicolumn{2}{|c|}{ EROTIC RELATION is SUFFERING / (PAIN) } \\
\hline Cuerpo dolorido & Aching body $\triangle$ ILLNESS \\
\hline Dolor espiritual y dolor del cuerpo & Spiritual and body pain $\boldsymbol{\Delta}$ ILLNESS \\
\hline Echar de menos & To miss \\
\hline Desilusión & Disappointment \\
\hline Someterse libremente al sacrificio & $\begin{array}{l}\text { To submit freely to the sacrifice } \\
+ \text { SUBMISSION }\end{array}$ \\
\hline \multicolumn{2}{|c|}{ EROTIC RELATION is SUBMERGENCE } \\
\hline Mi conciencia se anegaba en la suya & My conscience was drowning in his \\
\hline Inundar el amor en el placer & To flood the love with the pleasure \\
\hline Hundirse en el fondo del brocal & To sink in the bottom of the funnel \\
\hline Disuelto en el placer & $\begin{array}{l}\text { Dissolved in pleasure } \rightarrow * \text { DISSOLU- } \\
\text { TION }\end{array}$ \\
\hline \multicolumn{2}{|c|}{$\begin{array}{c}\text { EROTIC RELATION is TRANSGRESSION / LIBERATION OF } \\
\text { PRISONER }\end{array}$} \\
\hline $\begin{array}{l}{[\ldots] \text { todavía tengo las rozaduras de las }} \\
\text { esposas y de los grilletes en muñecas y } \\
\text { tobillos: residuos, resentimientos, ansie- } \\
\text { dades a los que aún no me atrevo a dar- } \\
\text { les libertad. }\end{array}$ & $\begin{array}{l}{[\ldots] \text { I have still chafing of the handcuffs }} \\
\text { and shackles on my wrists and ankles: } \\
\text { some waste, some resentment and anxi- } \\
\text { eties to which I don't even dare to give } \\
\text { freedom }\end{array}$ \\
\hline $\begin{array}{l}\text { Gozar de la libertad, efímera y compar- } \\
\text { tida, que lleva de la celda común a la } \\
\text { huida común. }\end{array}$ & $\begin{array}{l}\text { To enjoy the freedom, ephemeral and } \\
\text { shared, that leads from the shared cell } \\
\text { to the escape }\end{array}$ \\
\hline
\end{tabular}

Table 9

\subsection{Erotic relation is fog and a force of nature}

Other group which might be separated from the collection of metaphors listed in the beginning of section 6 has to do with some meteorological phenomena. It turns out that The Turkish Passion abounds in expressions that appear in the context of erotic relations and refer to the FOG and FORCE OF NATURE source domains. As it is reflected in the table below, Spanish tends to allude to some specific natural phenomena, like wind or earthquake, while referring to the erotic relations. Furthermore, it is important to highlight that the FORCE OF NATURE source domain has one metonymic extension. In some cases it entails the ROUGH SEA source domain (star marked example). At the same time, we may observe another evidence of overlapping metaphors, because in one context the conceptualization of 
erotic relation in terms of FOG coincides with one of the linguistic realizations of EROTIC RELATION IS ILLNESS metaphor (triangle marked example; $c f$. table 1)

\begin{tabular}{|l|l|}
\hline \multicolumn{1}{|c|}{$\begin{array}{c}\text { Antonio Gala The Turkish } \\
\text { Passion }\end{array}$} & \multicolumn{1}{c|}{ Literal English translation } \\
\hline \multicolumn{2}{|c|}{ EROTIC RELATION is FOG } \\
\hline $\begin{array}{l}\text { Las brumas del deseo que no dejan ver } \\
\text { la realidad }\end{array}$ & $\begin{array}{l}\text { The mists of desire that make impossible } \\
\text { to see the reality }\end{array}$ \\
\hline Las nieblas del deseo urgente & The mists of urgent desire \\
\hline Se me nubló de nuevo el mundo & $\begin{array}{l}\text { The world clouded over to me again } \\
\text { ILLNESS }\end{array}$ \\
\hline \multicolumn{2}{|c|}{ EROTIC RELATION is FORCE OF NATURE } \\
\hline La pasión aventa como un vendaval & $\begin{array}{l}\text { The passion throws oneself like a hurri- } \\
\text { cane } \\
\rightarrow \text { WIND }\end{array}$ \\
\hline Pradera sacudida por un terremoto & $\begin{array}{l}\text { The meadow struck by an earthquake } \\
\rightarrow \text { EARTHQUAKE }\end{array}$ \\
\hline Seísmo & Seism $\rightarrow$ EARTHQUAKE \\
\hline $\begin{array}{l}\text { Deseo como una ola que arrastra al } \\
\text { amante }\end{array}$ & $\begin{array}{l}\text { A desire as a wave that carries the } \\
\text { lover } \rightarrow \text { EROTIC RELATION IS } \\
\text { ROUGH SEA }\end{array}$ \\
\hline
\end{tabular}

Table 10

6.5. Erotic relation is a gift, magic, approaching the divine, waking up, unity, miracle, and the coexistence of opposites

Finally, we shall quote some examples of the less frequent, but still important, erotic relation conceptual metaphors in Spanish that appear in Antonio Gala's novel. A detailed study of the language employed by the author enabled us to establish 7 more source domains related to the erotic relations and encoded in Spanish. All of them, as well as some of their realizations in the book, are listed in the chart below. We did not observe any case of overlapping metaphors or source domain metonymic extensions. 


\begin{tabular}{|l|l|}
\hline \multicolumn{1}{|c|}{$\begin{array}{c}\text { Antonio Gala The Turkish } \\
\text { Passion }\end{array}$} & \multicolumn{1}{|c|}{ Literal English translation } \\
\hline \multicolumn{2}{|c|}{ EROTIC RELATION is A GIFT } \\
\hline Recibimiento / Entrega & Reception / Delivery \\
\hline Presencia del amante como obsequio & The presence of the lover as a gift \\
\hline \multicolumn{2}{|c|}{ EROTION is MAGIC } \\
\hline Embrujar a alguien & To charm someone \\
\hline Hechizar & To bewitch \\
\hline \multicolumn{2}{|c|}{ EROTIC RELATION is APPROACHING THE DIVINE } \\
\hline Transplantarse a alguien al séptimo cielo & To transfer someone to seventh heaven \\
\hline Un éxtasis divino, lindante con los dioses & $\begin{array}{l}\text { A divine ecstasy, bordering with the } \\
\text { gods }\end{array}$ \\
\hline \multicolumn{2}{|c|}{ EROTIC RELATION is UNITY } \\
\hline $\begin{array}{l}\text { Despertar el cuerpo / Despertar el pla- } \\
\text { cer }\end{array}$ & $\begin{array}{l}\text { To awaken the body/ To awaken the } \\
\text { pleasure }\end{array}$ \\
\hline \multicolumn{2}{|c|}{ EROTIC RELATION is A MIRACLE } \\
\hline $\begin{array}{l}\text { Una comunión de la carne más generosa } \\
\text { y más segura }\end{array}$ & $\begin{array}{l}\text { A communion of the flesh more generous } \\
\text { and more secure }\end{array}$ \\
\hline Hondos lazos de afecto & Deep bonds of affection \\
\hline \multicolumn{2}{|c|}{ ER } \\
\hline $\begin{array}{l}\text { Un hombre capaz de convertir el agua } \\
\text { en el vino }\end{array}$ & $\begin{array}{l}\text { A man capable of turning water into } \\
\text { wine }\end{array}$ \\
\hline Cumplirse el milagro & To realize a miracle \\
\hline EROTIC RELATION is THE COEXISTENCE OF OPPOSITES \\
\hline Amor: construcción y destrucción & Love: construction and destruction \\
\hline $\begin{array}{l}\text { Graves sufrimientos y grandísimos delei- } \\
\text { tes }\end{array}$ & Severe suffering and very great pleasures \\
\hline Sufrir y gozar & Suffer and enjoy \\
\hline
\end{tabular}

Table 11

\section{Conclusions}

Our analysis of the linguistic corpus from Antonio Gala's novel has revealed the existence of 24 conceptual metaphors of erotic relations in Spanish. We observe that among them there is a noticeable diversity in terms of frequency of their appearance in the book. The results of our study show that the predominant source domains to which Spanish refers in the context of erotic relations are: ILLNESS, WAR, DEATH, WARMTH, HUNGER, INNER TRANSFORMATION 
and the conceptualization of a person involved in erotic relation as an ANIMAL. Furthermore, our study of the linguistic material shows large collection of examples of overlapping metaphors (i.e. EROTIC RELATION IS ILLNESS and EROTIC RELATION IS FOG; EROTIC RELATION IS DEATH and EROTIC RELATION IS INNER TRANSFORMATION; EROTIC RELATION IS WAR and EROTIC RELATION is PHYSICAL FORCE etc.). At the same time we can observe that it is quite common that the princial source domain has some metonymic extensions (e.g. HUNGER $\leftrightarrow$ EATING / WARMTH $\leftrightarrow$ FIRE etc.). Since the object of our study has been a literary text, it remains to be seen if all metaphors included in our overview are elaborated by the everyday language. Unquestionably, as the ordinary language normally differs in some aspects from the artistic discourse, our analysis may result a bit far-going. Nevertheless, the analysis we propose enables us to observe a systematic use of erotic relation conceptual metaphors in Spanish.

Since the subject of this paper are the conceptual images of erotic relations in Spanish, to sum up, we would like to present our results as an image. In the graph below elaborated we have reconstructed and systematized the source domains by means of which the erotic relations are conceptualized in Spanish. The grey colour squares present the principal source domains, the black oval circles serve to mark their metonymic extensions (if present). The dotted lines show the overlapping of some metaphors and the crossed line denotes a group of meteorological metaphors.

\section{CONCEPTUAL IMAGES OF EROTIC RELATIONS IN SPANISH}

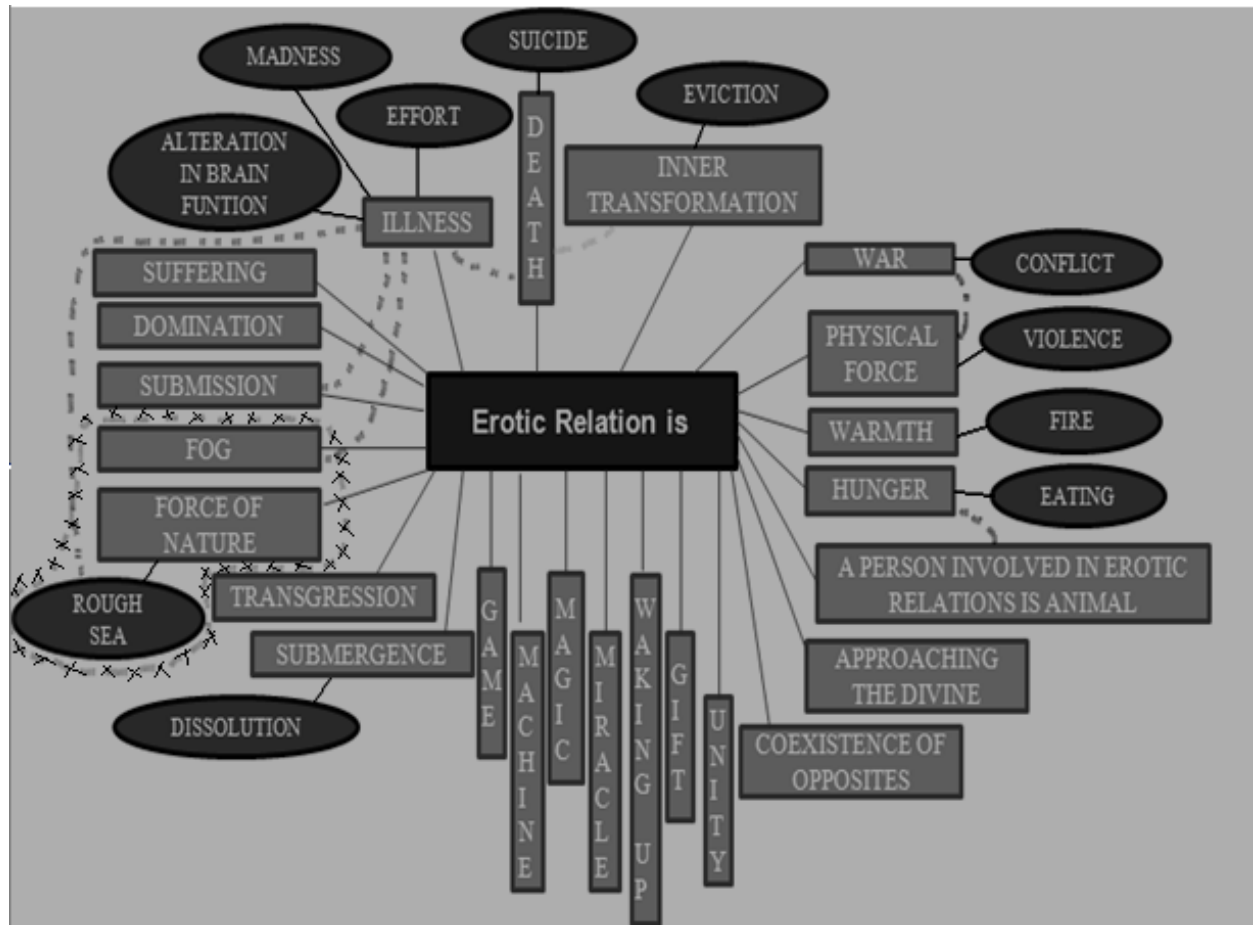

Graph 2 


\section{References}

Clave. Diccionario de uso del español actual (2003). Ediciones SM, Madrid.

Crespo Fernández, Eliecer (2008). Sex-Related Euphemism and Dysphemism: An Analysis in Terms of Conceptual Metaphor Theory, Atlantis. Journal of the Spanish Association of Anglo-American Studies, XXX.II, pages 95-110.

Gala, Antonio (2001). La pasión turca, Bibliotex, Barcelona.

García-Olivares, Antonio (2007). Metáforas del saber popular (III): el amor en el tango, Acciones e Investigaciones Sociales, XXIII, pages 139-179.

Kövecses, Zoltan (2000). Metaphor and Emotion. Language, Culture and Body in Human Feeling, Cambridge University Press, Cambridge.

Lakoff, George \& Johnson, Mark (1980). Metaphors We Live By, University of Chicago Press, Chicago and London.

Lakoff, George (1987). Women, Fire, and Dangerous Things. What Categories Reveal about the Mind, University of Chicago Press, Chicago \& London.

Muñoz Gutiérrez, Carlos (n.d.). Modelos cognitivos, http://www.ucm.es/info/pslogica/cognitivos.pdf, date of access: 15. Nov. 2010.

Nubiola, Jaime (2000). El valor cognitivo de las metáforas, Cuadernos de Anuario Filosófico, CIII, pages 73-84.

Schaff, Adam (1982). Wstęp do polskiego wydania, in: Bejamin Lee Whorf. "Język, myśl i rzeczywistość". Państwowy Instytut Wydawniczy, Warszawa, pages 5-29. 